Issued: October 1999

Nuclear Rapprochement in Argentina

and Brazil: Workshop Summary

James E. Doyle 


\section{DISCLAIMER}

This report was prepared as an account of work sponsored by an agency of the United States Government. Neither the United States Government nor any agency thereof, nor any of their employees, make any warranty, express or implied, or assumes any legal liability or responsibility for the accuracy, completeness, or usefulness of any information, apparatus, product, or process disclosed, or represents that its use would not infringe privately owned rights. Reference herein to any specific commercial product; process, or service by trade name, trademark, manufacturer, or otherwise does not necessarily constitute or imply its endorsement, recommendation, or favoring by the United States Government or any agency thereof. The views and opinions of authors expressed herein do not necessarily state or reflect those of the United States Government or any agency thereof. 


\section{DISCLAIMER}

Portions of this document may be illegible in electronic image products. Images are produced from the best available original document. 


\title{
Nuclear Rapprochement in Argentina and Brazil: Workshop Summary
}

\author{
James E. Doyle
}

\begin{abstract}
On October 21 and 22, 1998, the Center for International Security Affairs at Los Alamos National Laboratory and the Center for Global Security and Cooperation at Science Applications International Corporation hosted the first of a series of workshops on states that have chosen to roll back their pursuit of nuclear arms. The objective of the workshop series is to conduct a systematic evaluation of the roles played by U.S. nonproliferation policy in cases of nuclear rollback or restraint and to provide recommendations for future nonproliferation efforts based on lessons learned.

Key attendees at the workshop included officials and former officials from the foreign ministries of Argentina and Brazil, and current and former officials from the U.S. Department of State, the Arms Control and Disarmament Agency (ACDA), and the Department of Energy (DOE). Scholars and independent researchers who have examined nuclear policy in Argentina and Brazil also participated.

This workshop report includes important background information that helps set the stage for assessing nuclear policies in Argentina and Brazil. It describes national perspectives and areas of consensus and debate among the participants, particularly on the questions of lessons learned and their salience to proliferation challenges in other states. It also summarizes key questions and propositions regarding the roles played in these cases by U.S. nonproliferation policy.
\end{abstract}

\section{Introduction}

On October 21 and 22, 1998, the Center for Global Security and Cooperation at Science Applications International Corporation and the Center for International Security Affairs at Los Alamos National Laboratory hosted the first of a series of workshops on states that have chosen to roll back their pursuit of nuclear arms. The objective of the workshop series is to conduct a systematic evaluation of the roles played by U.S. nonproliferation policy in cases of nuclear rollback or restraint and to provide recommendations for future nonproliferation efforts based on lessons learned. 
The workshops provide a forum for the exchange of views between policymakers from the rollback countries and, to the extent possible, the U.S. officials who were responsible for implementing nonproliferation efforts toward those countries. In the cases of Argentina and Brazil, this approach yielded new perspectives that provided a clearer understanding of nuclear decisionmaking in these states. Insights gained during the workshop also may help improve the effectiveness of nonproliferation efforts by the United States and the international community.

Key attendees at the workshop included officials and former officials from the foreign ministries of Argentina and Brazil, and current and former officials from the U.S. Department of State, the Arms Control and Disarmament Agency (ACDA), and the Department of Energy (DOE). Scholars and independent researchers who have examined nuclear policy in Argentina and Brazil also participated.

The first day of the workshop opened with presentations by experts from Argentina and Brazil who provided important background information and an overview of events from a regional perspective. These were followed by sessions devoted to key phases in the evolution of nuclearpolicy making and perspectives from American participants, several of whom helped to formulate U.S. policy toward Argentina and Brazil.

The second day of the workshop focused on the decisions by Argentina and Brazil to join the Treaty on the Nonproliferation of Nuclear Weapons (NPT) and the role played by U.S. nonproliferation policy. These presentations led to a substantive discussion of the lessons learned from the evolution of nuclear-policy making in Argentina and Brazil. Finally, the question of whether these lessons could help improve nonproliferation efforts toward other states was considered.

This workshop report includes important background information that helps set the stage for assessing nuclear policies in Argentina and Brazil. It describes national perspectives and areas of consensus and debate among the participants, particularly on the questions of lessons learned and their salience to proliferation challenges in other states. It then sums up some key questions and propositions regarding the role of U.S. nonproliferation policy that can be examined during subsequent workshops in the series.

\section{Overview}

From the late 1960s through the 1980s, Argentina and Brazil made efforts to create independent nuclear power infrastructures. In the 1980s these infrastructures became capable of providing the materials and expertise for nuclear weapons. There is little evidence, however, that either of these two countries ever made a concrete decision to build nuclear weapons. ${ }^{1}$ Though

\footnotetext{
1 There is no evidence of weaponization in Argentina. In 1967, Brazil's National Council for Nuclear Energy (CNEN) commissioned a study of the feasibility of building an atomic bomb. See H. Jon Rosenbaum, "Brazil's Nuclear Aspirations," in Nuclear Proliferation and the Near-Nuclear Countries, ed. Onkar Marwah and Schulz (Cambridge: Ballinger, 1975). In 1978 Brazil launched a secret nuclear development program that proceeded in parallel to its acknowledged civil nuclear program. For some elements of the Brazilian military, the objective of this effort was to develop the capability to construct a nuclear explosive device. See Michael Barletta, "The Military Nuclear Program in Brazil," (unpublished manuscript, November 2, 1996), p. 8. In addition, former Brazilian Minister of Science and Technology Jose Goldemberg has stated that he believes a nuclear explosive would have been designed by the Brazilian Air Force at the Aerospace Technology Center near Sao Paulo. See David Albright, "Brazil Comes in From the Cold," Arms Control Today, December 1990, p. 13.
} 
conference participants from both countries expressed the strong conviction that the nuclear programs in both states were devoted entirely to non-military purposes, Argentina and Brazil generated suspicions regarding their nuclear intentions by constructing facilities that could produce bomb-grade nuclear materials and by refusing to accept international safeguards on all of their nuclear activities. In addition, throughout the 1970s and 1980s, both states refused to bring fully into force the terms of the Treaty of Tlatelolco, which established a nuclear-weapons-free zone in Latin America, or to join the Treaty on the Nonproliferation of Nuclear Weapons (NPT). Finally, political and military leaders in both countries often declared their right to explore a nuclear-weapon option and to be free to develop the capability for conducting so-called peaceful nuclear explosions (PNEs). ${ }^{2}$

Over time, Argentina and Brazil came to realize the negative consequences of refusing to foreswear a nuclear weapon option and the benefits of joining the international nonproliferation regime. This policy shift was preceded by an improving bilateral relationship that included measures to provide mutual confidence in the peaceful nature of their nuclear programs. The centerpiece of these efforts was the establishment of the Brazilian-Argentine Agency for Accounting and Control (ABACC) of nuclear activities in 1991. In the early 1990s, both countries brought the Treaty of Tlatelolco fully into force on their territories, renounced their right to conduct PNEs, and strengthened their nuclear export controls. Moreover, they created a joint system of inspections of all their nuclear facilities that includes accepting full-scope International Atomic Energy Agency (IAEA) safeguards. Both states canceled plans to build reprocessing plants and scaled back uranium enrichment capabilities. Argentina joined the NPT as a non-nuclear weapon state (NNWS) in 1995, and Brazil joined with the same status in 1998. In short, they have rolled back the ambiguity regarding their nuclear intentions and accepted verifiable political commitments foreswearing nuclear arms.

\section{Regional Motivations for Changes in Nuclear Policy}

Throughout the 1960s and 1970s, efforts by Argentina and Brazil to maintain a nuclear option were motivated in part by rivalry and mutual suspicion. Motivation to remain outside the nonproliferation regime stemmed from the perceived domestic political benefits of maintaining independent nuclear postures, from a belief in the economic benefits of advanced nuclear technology, and from the desire for international prestige. The view that nuclear energy development was an important determinant of overall economic and technological advancement and the corresponding belief that international controls on nuclear activities would constrain such advancement was particularly strong in both states. ${ }^{3}$ The political leadership in both nations rejected the NPT as

\footnotetext{
${ }^{2}$ In Brazil such statements started with General Costa e Silva, head of the military government in 1966. See Michael J. Siler, Explaining Variation in Nuclear Outcomes Among Southern States: Bargaining Analysis of U.S. Nonproliferation Policies Toward Brazil, Egypt, India, and South Korea, (Ph.D. dissertation, Univ. of Southern California, May 1992), p. 163. For additional statements see "Navy Minister Says Country Could Build a Nuclear Bomb," Foreign Broadcast information Service (FBIS)/LAT, June 29, 1981, p. D2; and "Army Minister said to Favor Building Atomic Bomb," FBIS/LAT, September 4, 1985, p. D2. For similar statements by Argentine leaders see Joseph Pilat and Warren Donnelly, An Analysis of Argentina's Nuclear Power Program and its Closeness to Nuclear Weapons (Washington, D.C.: Congressional Research Service, December 2, 1982), pp. 19-36.

3 Etel Solingen, "The Political Economy of Nuclear Restraint," International Security, vol. 19, no. 2 (Fall 1994).
} 
discriminatory and opposed efforts by the advanced nations to impose nuclear supplier guidelines that constrained Argentina's and Brazil's ability to acquire modern nuclear technology. 4

Moreover, Argentina and Brazil derived political benefits from supporting one another's decisions to remain outside the global nonproliferation regime. These benefits included a tacit mutual approval of their self-proclaimed right to develop nuclear explosive technology and the creation of an informal agreement to defy the nonproliferation regime. This agreement to maintain common policies toward the NPT guaranteed that neither state was singled out by the international community for refusing to join the treaty. Ironically, this strategy for mutual opposition to the NPT evolved into a mechanism for more substantive bilateral nuclear cooperation and eventual integration into the international nonproliferation regime.

There was a strong consensus among workshop participants that Argentina and Brazil reconsidered their independent nuclear posture because of the mutual realization that ambiguity regarding their nuclear intentions was an obstacle to improving their bilateral relationship. In Argentina after 1989 there was also a strong belief that nuclear ambiguity prevented achieving a key foreign policy goal: improving relations with the United States. ${ }^{5}$

The leadership of both states concluded that continued pursuit of a nuclear option would entail political and economic costs without supporting strategic national objectives. These costs would hinder the achievement of other important national objectives such as modernization and technological development. ${ }^{6}$ This shift in attitude occurred over a period of approximately fifteen years and was accelerated in the late 1980s by the transition to democratic rule in both countries.

A key feature of nuclear rapprochement in Argentina and Brazil was the high degree of bilateral cooperation between the nuclear policies of the two states. This cooperation was possible because Argentine and Brazilian security concerns about each other were never overriding. This fact weakened national security arguments for the development of nuclear weapons. Instead, both countries saw an opportunity to improve their security and economic prospects through a reduction in the tensions produced by the nuclear competition. ${ }^{7}$

\section{A. Key Factors: Bilateral Diplomacy and Transition to Democracy}

Participants agreed that a sustained series of successful bilateral diplomatic actions that were focused on nuclear issues, was the catalyst to the transformation of nuclear policy in Argentina and Brazil. Even before either country had mastered the technology to produce weapon-usable nuclear material, they reached an initial agreement for peaceful nuclear cooperation. In January 1977, the Argentine and Brazilian foreign ministries issued a joint communique stressing the importance of nuclear policy cooperation and the initiation of systematic technological exchanges between the two countries' respective nuclear energy commissions. In May 1980, Brazil's military leader, Joao

\footnotetext{
${ }^{4}$ Leonard Spector, Nuclear Proliferation Today (New York: Random House, 1984), pp. 195-269.

5 Julio C. Carasales, "External Influences on the Nuclear Policy of Argentina," Unpublished manuscript prepared for the Argentina and Brazil Rollback Workshop, SAIC Center for Global Security and Cooperation, October 1998, pp.10-11.

6 Pedro Villagra Delgado, “The Road to ABACC," Unpublished manuscript prepared for the Argentina and Brazil Rollback Workshop, SAIC Center for Global Security and Cooperation, October 1998, p. 3.

7 Julio C. Carasales, “The Argentine-Brazilian Nuclear Rapprochement," The Nonproliferation Review 2 (Spring-Summer 1995).
} 
Figueiredo, visited Buenos Aires and signed an agreement between the two national nuclear commissions (CNEA in Argentina and CNEN in Brazil) that included joint research and development on nuclear power reactors, exchange of nuclear materials, uranium prospecting, and the manufacture of fuel elements. ${ }^{8}$

The deepening nuclear cooperation between the two countries was facilitated by an improving political relationship and the resolution of key bilateral disputes. In October 1979 Argentina, Brazil, and Paraguay signed the Rio de la Plata agreement that resolved a dispute over the use of water resources and the construction of a hydroelectric dam on the Parana River that flows from Brazil into Argentina. This agreement eased bilateral tensions that had persisted throughout the 1970s over the exploitation of the fertile Rio de la Plata basin and marked the beginning of an improved phase of Argentine-Brazilian relations. ${ }^{9}$

Another breakthrough that improved political relations and nuclear cooperation between Argentina and Brazil was the emergence of civilian governments in the mid-1980s. In Argentina, military defeat in the Malvinas/Falkland Islands war with Great Britain led to the October 30, 1983, election of President Raul Alfonsin. In 1984, an economic crisis in Brazil forced the military government to step down and permit civilian elections. Brazil's new president-elect Tancredo Neves met Alfonsin in February 1985. The two leaders promised to revive nuclear cooperation and to work toward the goal of mutual inspections of each other's nuclear installations. ${ }^{10}$

Unfortunately, Brazilian president-elect Neves died before taking office in March, and his successor, Jose Sarney, did not support the proposed nuclear inspection arrangement. Sarney nevertheless met with Alfonsin in November 1985 and signed the "Argentine-Brazilian Joint Declaration on Nuclear Policy" (the Declaration of Iguazu). This declaration reemphasized the two states' mutual commitment to develop nuclear energy for exclusively peaceful purposes, promote close cooperation in the nuclear field, and coordinate acquisition of nuclear equipment and materials. ${ }^{11}$ It also established a Joint Committee on Nuclear Policy to continue the bilateral dialogue on nuclear matters, including inspections of facilities. ${ }^{12}$ This committee, composed of the foreign ministers, officials from CNEA and CNEN, and industry representatives, became a mechanism for continuous contact on nuclear policy and nonproliferation issues. In July 1986 Alfonsin and Sarney signed a major trade agreement committing their nations to the phased elimination of trade barriers and the creation of a Southern Cone Common Market (MERCOSUR). This agreement

\footnotetext{
${ }^{8}$ Foreign Broadcast Information Service (FBIS), Nuclear Development and Proliferation, (June 25, 1980), pp. 4-16. Also see Leonard S. Spector with Jacqueline R. Smith, Nuclear Ambitions: The Spread of Nuclear Weapons, 1989-1990 (Boulder, CO: Westview, 1990), pp. 388-389.

9 John R. Redick, "Nuclear Mlusions: Argentina and Brazil," Occasional Paper 25, The Henry L. Stimson Center, December 1995, p. 20.

10 Richard Kessler, "Argentina, Brazil Agree to Mutual Inspection of Nuclear Facilities," Nucleonics Week, March 14, 1985, p. 14.

11 See Julio Cesar Carasales, "A Unique Component of the New Argentine-Brazilian Relationship: Nuclear Cooperation," in Averting a Latin American Nuclear Arms Race, Paul L. Leventhal and Sharon Tanzer, eds., (New York: St. Martin's Press, 1992) and John R. Redick, "Argentina and Brazil: An Evolving Nuclear Relationship," Occasional Paper Seven (Southampton, U.K.: Program for Promoting Nuclear Non-Proliferation, 1990).

12 This committee had three subgroups to deal with technical cooperation, foreign policy coordination, and the legal and technical aspects of nuclear cooperation.
} 
included plans for cooperation on nuclear safety in the event of an accident; a subsequent presidential meeting in December 1986 resulted in agreements for joint research on breeder reactors and the development of safeguards techniques. 13

\section{B. The Diplomacy of Mutual Inspections}

In the opinion of several of the conference participants, success in improving bilateral relations and the mutual confidence-building in the nuclear area were key to changes in nuclear policies. Mutual inspections achieved the objective of establishing respect and dialogue on an equal basis and eventually broke down suspicions regarding the purposes of the respective nuclear programs. As a result, when the two countries in 1991-92 moved to put in place a bilateral system of accounting and control, it was based on the concept of "neighbors watching neighbors." The backbone of this system, ABACC, had a solid political foundation and was much more than a mutual hedge against the uncertain intentions of rival states.

More specifically, in December 1986, Brazil allowed Argentine nuclear officials to visit the laboratory-scale facility at IPEN, where it's the Brazilian Navy had secretly conducted research on both uranium enrichment and reprocessing outside of IAEA safeguards. ${ }^{14}$ In advance of a September 1987 public announcement of the successful operation of the uranium enrichment facility at IPEN, Brazilian President Sarney sent a letter to President Alfonsin of Argentina notifying him of the upcoming public announcement. This action reciprocated the prior notice that Argentina had given Brazil regarding its enrichment plant in 1983. These actions and the previous meetings of the presidents led to an invitation from President Alfonsin to President Samey to visit Argentina's unsafeguarded Pilqaniyeu enrichment facility. The visit, which took place in July 1987, was an important confidence-building measure and prompted discussions on formalizing the process.

The process of reciprocal inspections and confidence-building continued with a second visit by Argentine officials to Brazil's IPEN facility in April 1988 and Brazilian officials' visit to Argentina's Ezeiza pilot reprocessing facility in November 1988. Once again, the process was boosted by domestic political developments. In August 1989, Argentina's new President, Carlos Menem, met with Sarney in Brazil to agree on additional measures of nuclear cooperation and to intensify bilateral political and economic coordination. In response to congressional pressure in Brazil, President Samey had combined the official and secret military nuclear programs under a reorganized CNEN that reported directly to his office. ${ }^{15}$ In December 1989 Fernando Collor de Mello was elected president in Brazil and replaced Sarney in March 1990.

There were now popular Presidents in both Argentina and Brazil who were committed to economic reform, increased trade and foreign investment, reduction of the military's influence, and the exclusively peaceful use of nuclear energy. The two presidents saw nuclear cooperation as a way to accelerate the bilateral political and economic coordination that was already underway. On November 28, 1990, Presidents Collor and Menem signed the landmark Joint Declaration of Common Nuclear Policy at Foz de Iguazu. Both countries pledged to use nuclear energy only for

\footnotetext{
13 Redick, Nuclear Illusions, p. 21.

14 Richard Kessler, "Sarney Visit to Pilqaniyeu Was Key to Reciprocal Inspections," Nucleonics Week, July 23, 1987.

15 Redick, Nuclear Illusions, p. 23.
} 
peaceful purposes, create a formal system of bilateral inspections, and adhere jointly to the Treaty of Tlatelolco. They also pledged to develop mechanisms for the acceptance of full-scope IAEA safeguards. ${ }^{16}$

This declaration was implemented in July 1991 at the foreign ministers' meeting in Guadalajara, Mexico. The Guadalajara Accord established the Joint System of Accounting and Control of Nuclear Materials (SCCC), whose purpose was to verify that no nuclear materials were diverted for military purposes. Under this accord, the two countries renounced the right to conduct peaceful nuclear explosions. It was under this accord that the ABACC was created, modeled on the multipartite inspection system set up by the European Atomic Energy Community (Euratom). ${ }^{17}$

ABACC began operations in July 1992 and initially monitored nuclear installations in Argentina and Brazil that were not under IAEA safeguards. These bilateral safeguards arrangements went a long way toward demonstrating that Argentina and Brazil were no longer seeking a nuclear-weapon option. However, they were not yet sufficiently integrated with the IAEA safeguards system to convince major nuclear suppliers such as the United States, Canada, and Germany to lift nuclear export controls.

To satisfy these concerns and fulfill the pledge regarding full-scope safeguards made at Foz de Iguazu, Presidents Collor and Menem flew to Vienna in December 1991 to sign a Quadripartite Agreement among Brazil, Argentina, the ABACC, and the IAEA. Under this agreement, the two countries affirmed that international safeguards would apply "on all nuclear material in all nuclear activities within their territories ... for the exclusive purpose of verifying that such material is not diverted to nuclear weapons or other nuclear explosive devices." The Quadripartite Agreement was ratified by Argentina and Brazil and entered into force on March 4, 1994, bringing all nuclear activities in Argentina and Brazil under international safeguards. In addition, by the end of May 1994, both countries had ratified a revised Treaty of Tlatelolco in which the IAEA played a larger

role. ${ }^{18}$ The continued application of nuclear energy for military purposes by either state was clearly inconsistent with the intent of these agreements. Moreover, there was now an international monitoring system in place to guarantee the peaceful nature of the nuclear programs.

\section{The Role of Outside Actors}

One of the workshop objectives was to assess the role that outside actors played in this evolution of nuclear policy in Argentina and Brazil. This assessment began with a discussion of regional nonproliferation activities and the role of nongovernmental organizations (NGOs). Most conference participants agreed that only a modest role was played by these actors but also agreed that their influence is important to understand because it may be of greater importance in other cases. In cases where direct dialogue with or between proliferant states is unlikely, collaboration with NGOs or regional nonproliferation agendas can be an alternative course of action.

\footnotetext{
16 Redick, Nuclear Illusions, p. 24.

17 Reiss, Bridled Ambition, p. 61.

18 "Brazil, Argentina and Chile Bring into Force the Treaty for the Prohibition of Nuclear Weapons in Latin America and the Caribbean," U.S. Arms Control and Disarmament Agency Fact Sheet, ACDA Office of Public Information, June 3, 1994.
} 


\section{A. Nongovernmental Organizations}

In the cases of Argentina and Brazil, certain actions by NGOs facilitated an exchange of views on nuclear matters among Latin American and non-Latin American experts and diplomats. 19 Approaches to regional or bilateral nuclear arms control were often proposed and assessed during these exchanges. An early example of such activity is a 1978 Stanley Foundation Conference on Energy and Nuclear Security in Latin America held in Antigua involving high-level officials from Latin American nuclear programs and major suppliers such as the United States, Canada, and Europe. Confidence-building measures such as information-sharing, exchanges of technical experts, and joint research projects were discussed.

Another NGO-sponsored conference that came at a critical juncture in the evolution of nuclear policy in Argentina and Brazil occurred in October 1989 in Montevideo, Uruguay. This conference was organized by the Nuclear Control Institute (NCI) of the United States and financed by the Ford Foundation. Three former directors of the Argentine CNEA and many important Argentine and Brazilian officials, including Jose Goldemberg (who would later oversee Brazil's nuclear program as Minister of Science and Technology), attended the conference. The American participants included Nuclear Control Institute staff, former government officials, industry representatives, academics, and U.S. national laboratory personnel. Topics discussed included bilateral and international safeguards, economic advantages of nuclear cooperation, and the international nonproliferation regime. ${ }^{20}$ Several workshop participants believed that the Montevideo conference helped communicate to officials from Argentina and Brazil that only acceptance of full-scope multilateral safeguards-not a bilateral system - would alleviate international nonproliferation concerns and end the application of export controls and economic sanctions.

A third significant NGO activity was the work of the Federation of American Scientists (FAS) and the Institute for Science and International Security (ISIS) with the Argentine and Brazilian Physics Societies. ${ }^{21}$ Beginning in 1988, the FAS gave technical advice to the Brazilian Physical Society Commission on nuclear safeguards, facility inspections, and measurement and verification techniques. FAS representatives conducted a series of workshops in December 1988 at the University of Rio de Janeiro on nuclear safeguards and mechanisms for U.S. government oversight of its nuclear programs. These workshops resulted in an initiative to bring Brazilian officials to the U.S. to learn about U.S. congressional oversight of civil and military nuclear programs. In the early 1990s, FAS and ISIS staff traveled to Argentina to meet with members of the Argentine Physics Association who had also formed a committee to increase civilian oversight of nuclear activities in their country. ${ }^{22}$ These unofficial contacts helped suggest to Argentine and Brazilian officials that safeguards procedures already developed through the multilateral Hexapartite Safeguards Project could provide a model for safeguards at Brazil's sensitive Aramar enrichment plant.

19 Address by John Redick prepared for the Argentina and Brazil Rollback Workshop, SAIC Center for Global Security and Cooperation, October 1998, p. 1.

${ }^{20}$ Leventhal and Tanzer, Averting a Latin American Nuclear Arms Race, pp. 68-74.

21 David Albright and William Higinbotham, "FAS Nonproliferation Experts Provide Technical Assistance to Brazilian Physical Society," F.A.S. Public Interest Report, vol. 42, no. 2, (February 1989), pp. 3-4.

22 Ibid. 


\section{B. Regional Nonproliferation Mechanisms}

For the most part the contribution of regional-as opposed to bilateral-activities to the Argentine-Brazilian nuclear rapprochement, participants believed, was minor. However, the nuclear-weapon-free-zone agreement embodied in the 1967 Treaty of Tlatelolco first prompted Argentina and Brazil to develop a common position on sensitive nuclear areas. For many years this common position was opposition to the international nonproliferation regime and related export controls. The pledges by both states not to take any actions contrary to the treaty also provided an important bilateral confidence building message that neither state was pursuing nuclear arms. Eventually the treaty was important as a regional framework in which an innovative bilateral inspection and verification regime could flourish. ${ }^{23}$

\section{Roles Played by U.S. Nonproliferation Policy}

Most conference participants asserted that the United States had only a limited direct influence on the transformation of the nuclear policies in Argentina and Brazil that most reflected both countries' changed domestic and foreign policy goals. Nevertheless, several policy approaches taken by the United States were identified as having had a positive effect in reinforcing trends and calculations in both countries. A few participants claimed that Washington sometimes took positions or actions that hindered progress toward nuclear rapprochement. There was also debate over how much the implementation of U.S. policy changed under different administrations and what effects these changes may have had on nonproliferation goals.

U.S. nonproliferation policy towards Argentina and Brazil was described as having at least the following five major elements:

1. Provide nuclear assistance in exchange for commitments by the two states to pursue exclusively peaceful nuclear programs. It was the U.S. objective that these commitments include adherence to the Treaty of Tlatelolco, the NPT, and full participation with the global nonproliferation regime.

2. Oppose the transfer to or development of sensitive nuclear technologies such as uranium enrichment, reprocessing, or heavy-water reactors in Argentina and Brazil.

3. Secure agreement among nuclear suppliers to condition assistance to the Argentine and Brazilian nuclear programs on their acceptance of IAEA safeguards on all of their nuclear activities (so-called full-scope safeguards).

4. Engage in constructive nonproliferation dialogue while pursuing limited peaceful nuclear cooperation.

5. Maintain and promote international nonproliferation norms.

\section{Nuclear Assistance}

Attempts by the United States in the 1970s and 1980s to gain leverage over the nuclear policies of Argentina and Brazil by providing assistance to their nuclear programs were not very successful. Restrictions imposed on nuclear assistance to Latin America after the Indian nuclear explosion of 1974 and the German nuclear deal with Brazil in 1975 meant that the United States had little

23 Address by John Redick, prepared for the Argentina and Brazil Rollback Workshop, SAIC Center for Global Security and Cooperation, October 1998, p. 4. 
influence over nuclear programs in the region. U.S. efforts to stop the German deal damaged the U.S.-Brazilian relationship. The German deal demonstrated the loss of leverage experienced by the United States after the emergence of alternative nuclear suppliers.

By contrast, there was broad agreement that U.S. nuclear assistance did play a positive role as the process of bilateral nuclear rapprochement evolved. Washington's technical assistance for IAEA safeguards in the region introduced Argentine and Brazilian officials to nuclear safeguards techniques they would later apply in their concept of a comprehensive safeguards regime integrated into the IAEA system. ${ }^{24}$ In addition, U.S. willingness to increase its technical assistance was essential to the successful implementation of ABACC and the Quadripartite Agreement. U.S. technical support for safeguards in South America provided practical examples of mechanisms that could be used to provide mutual confidence that nuclear facilities were not being used for the development of nuclear arms.

After the November 1990 Joint Declaration of a Common Nuclear Policy and the formation of ABACC, the U.S. Department of Energy (DOE) signed agreements with ABACC and CNEN concerning nuclear material accounting, verification, physical protection, and advanced containment and surveillance. DOE also began direct assistance for the design of a safeguards regime for Argentina's gaseous-diffusion plant at Pilcaniyeu and continued to work on reducing the enrichment of fuels for Argentine and Brazilian research reactors. ${ }^{25}$ In addition, U.S. voluntary funding of the IAEA's Program of Technical Assistance to Safeguards (POTAS) supported the purchase of advanced safeguards monitoring equipment by ABACC. ${ }^{26}$ The U.S. Nuclear Regulatory Commission also signed nuclear safety agreements with its Argentine and Brazilian counterparts.

U.S. safeguards assistance-which began well before the creation of ABACC with the training of many experts from both countries in U.S.-sponsored workshops and courses-was cited as a key factor in allowing the first bilateral inspections to occur six months after the formation of ABACC. Several conference participants specifically mentioned the nuclear safeguards training and assistance that Argentines and Brazilians received from Los Alamos National Laboratory as a factor that facilitated the creation of $\mathrm{ABACC}$ and the signing of the Quadripartite Agreement. This assistance allowed officials from the two countries to speak the same language concerning safeguards methods and technologies. Without this assistance, it would have been impossible to implement safeguards so rapidly. 27

\section{E. Export Controls and Nuclear Supplier Agreements}

The United States first used export controls in the 1950s to prevent Argentina and Brazil from acquiring the enrichment or reprocessing technology that would allow them to produce

\footnotetext{
24 Jose Goldemberg and Harold A. Feiveson, "Denuclearization in Argentina and Brazil," Arms Control Today, vol. 24., no. 2, (March 1994), pp. 10-14.

25 Tom Zamora Collina and Fernando de Souza Barros, Transplanting Brazil and Argentina's Success, ISIS Report vol. 2, no. 2, (Washington, D.C., Institute for Science and International Security, February 1995), p. 6.

26 The President's Section 601 report to Congress noted that, “...DOE is assisting Argentina, Brazil and the ... (ABACC) in developing nuclear safeguards capabilities in preparation for the application of full-scope safeguards. Specific activities include preparation of inspector and operator training programs, joint development of safeguards systems for uranium enrichment plants, and participation in nondestructive assay technology development and evaluation programs, and in chemical assay intercomparison experiments." Section 601 Report: 1993, op. cit. 27 Comments by Marco Marzo, Senior Officer for Planning and Evaluation at ABACC.
} 
weapons-grade nuclear material. After the NPT came into force, U.S. export controls were designed to encourage Argentina and Brazil to accept safeguards on all nuclear activities and to. deny technology and materials that could be used to expand unsafeguarded nuclear activities or contribute to nuclear-weapon programs.

In the mid-to-late 1970s, after India's nuclear test and France's initial decision not to sign the NPT, a key dimension of U.S. export-control strategy was the creation of the Nuclear Suppliers Group to strengthen and harmonize the export-control policies of the nuclear suppliers. This effort took on greater importance after it became clear that several key states, in particular Germany, were willing to transfer enrichment and reprocessing technology to Argentina and Brazil. Initially, the U.S. appeals to other nuclear suppliers to deny this sensitive technology were rejected, and both Argentina and Brazil acquired enrichment technology from other states.

However, the U.S. strategy began to succeed in the late 1980s, when Germany, France, and the United Kingdom began to join the United States and Canada in requiring IAEA safeguards on all recipient nuclear facilities as a condition of supply. U.S. nuclear and dual-use export controls imposed on Argentina and Brazil, and other nuclear suppliers' eventual decisions to impose similar controls, ultimately slowed the completion of nuclear projects and raised their costs. For example, aggressive U.S. diplomacy during the early to mid-1980s prevented some states from supplying Argentina's Ezeiza reprocessing plant with key components, blocking its completion. ${ }^{28}$ Delays of this type increased the domestic constraints of the nuclear programs in both countries, particularly as nuclear proponents had to justify the nuclear programs relative to other national priorities.

The positive effect that export controls appears to have had in slowing nuclear programs has to be balanced against other negative consequences of the technology denial strategy. These consequences included damage to U.S. relations with these countries, intensification of their efforts to acquire nuclear technology from other suppliers, increased resolve to develop indigenous nuclear capabilities outside of international safeguards, and political cooperation to oppose the international nonproliferation regime. Some conference participants speculated that the U.S. policy of nonproliferation export controls actually had decreased the chances that Argentina and Brazil would join the nonproliferation regime. Most participants agreed that export-control policies and corresponding diplomatic actions should have been implemented in a less heavy-handed way. Several participants asserted their view that the Reagan Administration had greater success than the Carter Administration in dealing with Argentina and Brazil because of the more flexible manner in which it implemented export controls.

\section{F. Maintaining a Constructive Nonproliferation Dialogue}

From the early 1980s onward, the United States sought to reestablish a constructive nonproliferation dialogue with Argentina and Brazil despite political acrimony over North-South political issues, the NPT, the Nuclear Suppliers Group, and the constraints of the U.S. Nuclear Nonproliferation Act of 1978 (NNPA). The United States hoped this nonproliferation dialogue would reassure each country that the other was not involved in developing nuclear weapons and would encourage and support confidence-building measures. This dialogue was ultimately successful in creating an improved climate for multilateral cooperation and encouraging Argentine-Brazilian nuclear transparency. U.S. efforts to keep the lines of communication open and engage Argentina

28 Author's conversation with Lewis Dunn, April 1997. 
and Brazil across a broad range of issues despite tensions over nuclear matters proved most valuable once these two states decided to formalize their non-nuclear-weapon status.

During the period 1988-1994 the United States used its nonproliferation dialogue with Argentina and Brazil to encourage the landmark nuclear safeguards agreements of 1990 and 1991. In general, the United States used this dialogue to propose and initiate cooperative activities with Argentina and Brazil that were of mutual interest and that could lessen the ambiguity of their nuclear postures. ${ }^{29}$ By late 1988, the United States began broadening its nonproliferation dialogue, offering Argentina and Brazil access to supercomputers, nuclear safety equipment, environmental monitoring techniques, and satellite technology in exchange for further nonproliferation commitments. ${ }^{30}$ The result was a series of agreements with the United States providing greater access to technology for Argentina and Brazil, removing export restrictions previously imposed upon them, and allowing them greater participation in international export-control regimes. These events proceeded in parallel with Argentine and Brazilian acceptance of international inspections of their nuclear facilities and greater political commitments of nuclear nonproliferation. 31

\section{G. Supporting International Nonproliferation Norms}

U.S. leadership of the nonproliferation regime and its advocacy of the NPT helped demonstrate to Argentina and Brazil that their acquisition of nuclear arms would be met with international condemnation. ${ }^{32}$ U.S. promotion of the NPT, its decision to require full-scope safeguards as a condition of supply to both parties and non-parties to the NPT, and its advocacy of this policy through an expanded NSG demonstrated its commitment to nonproliferation in the region and its role of the standard-bearer of the nonproliferation regime. This role ultimately helped convince other states to restrict their nuclear cooperation with Argentina and Brazil.

U.S. nuclear-arms reductions and pledges to stop the production of fissile material for weapons purposes undercut arguments by Argentina and Brazil that the nuclear-weapon states were unwilling to reduce or control their own nuclear arsenals. These arguments had often been used to justify maintenance of a nuclear-weapon option. ${ }^{33}$ Participants noted that Latin American countries continue to be unsatisfied with U.S. progress under Article VI while recognizing some

29 This was the basic goal of a nonproliferation strategy of "constructive engagement" as practiced by Ambassador Richard Kennedy and others. See Spector, Nuclear Proliferation Today, p. 216. A key part of this strategy, especially during the Reagan and Bush administrations, was to renew and expand military assistance to Argentina and Brazil. This policy may have been instrumental in easing regional security concerns, thus undercutting the military rationale for nuclear weapons. It also demonstrated U.S. willingness to improve relations with these two states across a broad front. See Peter Clausen, Nonproliferation and the National Interest: America's Response to the Spread of Nuclear Weapons, (New York, Harper-Collins, 1993), pp. 176-177.

30 For example, the Bush administration supported the sale of supercomputers to Brazil in 1990 . However, in order to overcome the opposition of the U.S. Congress to the sale, Brazil sent two government ministers, including Jose Goldemberg, who directed Brazil's nuclear program as Minister of Science and Technology, to reassure Washington of Brazil's nonproliferation commitments. The sale was ultimately approved: See David Albright, "Brazil Comes in From the Cold," Arms Control Today, vol. 20, no. 10, (December 1990), p. 16.

31 In August 1991 NASA signed an agreement with the Argentine Space Research Commission for the joint development of Argentina's first satellite.

32 Lewis A. Dunn, "The NPT: It's Not Broken, So Don't Fix It," Bulletin of the Atomic Scientists, June 1990.

33 Ruth Stanley, "Co-operation and Control: The New Approach to Nuclear Nonproliferation in Argentina and Brazil," Arms Control, vol. 13, no. 2 (September, 1992), p. 194. 
progress in this area. Conference discussion demonstrated the importance of continued nucleararms reductions and related pledges in maintaining support of Latin American NNWS for the NPT.

\section{H. Other U.S. Policies Influencing Proliferation Outcomes}

Two other aspects of U.S. foreign policy were believed by some conference participants to have had a positive influence on the evolution of nuclear policies in Argentina and Brazil. These policy initiatives were not directly related to U.S. nonproliferation policy but seem to have had positive proliferation consequences. They are support for economic liberalization and regional security cooperation.

\section{Support for Economic Liberalization}

Several conference participants agreed that U.S. regional promotion of economic liberalization policies and the links between investment, technology transfer, and nonproliferation strengthened constituencies within Argentina and Brazil that supported multilateral nuclear safeguards and opposed rejection of the nonproliferation regime. ${ }^{34}$ U.S. advocacy of economic liberalization policies had its greatest influence on nuclear matters in Argentina and Brazil in the late 1980s and early 1990s when views on economic policies in these countries began to echo approaches promoted by the United States. In 1990, both President Menem of Argentina and Brazil's Collor implemented radical economic liberalization policies designed to reduce inflation, balance state budgets, privatize public services, attract foreign investment, and renegotiate foreign debt payment. 35

Over time, important constituencies in Argentina and Brazil acknowledged U.S.-style economic liberalization policies as the best route to regional economic dynamism. Increasingly, these groups concluded that state-financed maintenance of unsafeguarded nuclear activities and the resulting economic penalties imposed by the international nonproliferation regime created obstacles to domestic, bilateral, and international commerce. Growing support for internationalist foreign and economic policies led these groups to conclude that only acceptance of full-scope multilateral safeguards-not a bilateral system - would alleviate international nonproliferation concerns and end the application of export controls and economic sanctions. Some conference participants asserted that the view that ambiguity regarding nuclear intentions and rejection of the nonproliferation regime were obstacles to economic growth has been vindicated. These participants noted that in 1985, at the time of the first bilateral nuclear cooperation agreement, the annual value of Argentine-Brazilian trade was approximately $\$ 1$ billion. By 1998, after both states joined the NPT, annual trade was valued at nearly $\$ 15$ billion.

\section{J. Security Issues}

Several conference participants also supported the view that, in the case of Argentina, U.S. diplomacy related to the security field played an important role in overcoming the objections raised by the military to the nonproliferation regime. ${ }^{36}$ In 1992, Argentina had decided that it could no

\footnotetext{
34 Policies of economic liberalization generally include a reduction of state control over markets and barriers to trade, an expansion of private economic transactions and foreign investment, and the privatization of public sector enterprises. See Solingen, "The Political Economy of Nuclear Restraint," p. 137.

35 Etel Solingen, "Macropolitical Consensus and Lateral Autonomy in Industrial Policy: The Nuclear Sector in Brazil and Argentina," International Organization, vol. 42, no. 2, (1993), pp. 263-98.

36 Enrique de la Torre, "The Road to the Nonproliferation Treaty," prepared for the Argentina and Brazil Rollback Workshop, SAIC Center for Global Security and Cooperation, October 1998, p. 13.
} 
longer achieve security through its military forces alone because they could not be maintained at a level that could reliably defeat its potential adversaries in the region. Improving relations with the United States, other regional countries, and even NATO therefore became a key national security strategy. The United States responded favorably to Argentina's overtures by organizing a First Hemispheric Meeting of Defense Ministers in Williamsburg, Virginia in 1995 and granting Argentina non-NATO Ally status. It also resumed some programs of military assistance. These developments were consistent with the emergence of Argentina's internationalist foreign and economic policies and reduced security concerns.

\section{Applying the Lessons from Argentina and Brazil: Promoting Nuclear Rollback in Other States}

The workshop considered lessons learned in the case of Argentina and Brazil that might assist nonproliferation efforts elsewhere-or at least without considerable adaptation. The majority of conference participants believed that the context of proliferation and nonproliferation varies so much between states that they were skeptical that lessons from one case could be applied successfully elsewhere. In addition, there was broad agreement that it will be more difficult to reduce motivations for the acquisition of nuclear weapons in countries of proliferation concern such as Iran, Iraq, and North Korea because motivations are much stronger than they were in Argentina and Brazil. Nevertheless there was broad agreement that some general guidelines had emerged during discussions that might help improve U.S. and international nonproliferation efforts. These guidelines are summarized below.

\section{A. Keep Talking: It's Never Over Until It's Over}

Establishing and maintaining a nonproliferation dialogue with potential proliferators is an important element of nonproliferation strategy. Such a dialogue allows for discussion of cooperative activities that might be of interest to a potential proliferator and the specific changes in its nuclear behavior that would be needed to initiate them. This dialogue should be insulated as much as is feasible from disputes on other issues. Maintaining this dialogue can be of vital importance in speeding and shaping a desirable outcome if positive changes occur within a state independent of U.S. and international diplomacy. For example, in Argentina and Brazil a pre-existing nonproliferation dialogue was used by Washington to help encourage the integration of these states into the nonproliferation regime and to revitalize nuclear cooperation and trade.

\section{B. Constructive Engagement Works Better Than Pressure}

During the mid-to-late 1980s, U.S. dialogue on nuclear matters with Argentina and Brazil improved. This improvement corresponded with bilateral steps toward bilateral safeguards and the nonproliferation regime. The main reason for this improved dialogue was a greater flexibility on civilian nuclear cooperation in Washington and a concerted effort to introduce a more positive tone in U.S. discussions with Argentina and Brazil on nuclear nonproliferation. A new willingness to support bilateral confidence-building measures and provide nuclear safeguards assistance was part of this strategy. This approach led to more progress than diplomacy-based political condemnation and technology denial.

It may be beneficial to look for opportunities where U.S. foreign policy can support bilateral initiatives that can have positive proliferation consequences. For example, river diplomacy in 
Argentina accelerated bilateral cooperation in the nuclear area. The current initiative to expand upon "bus diplomacy" in India and Pakistan, should receive strong U.S. support.

\section{Export Control Strategies Are a Wasting Asset}

As German and Swiss assistance to the Argentine and Brazilian nuclear programs demonstrate, U.S. nuclear export controls can be circumvented by agreements with other nuclear suppliers. As nuclear technology has spread, the number of potential nuclear suppliers has increased. It has also become more difficult, if not impossible, to win the agreement of all suppliers to deny nuclear assistance to a given state. This limits the effectiveness of technology denial strategies. In addition, the U.S. imposition of nonproliferation export controls usually damages its overall relationship with the sanctioned country, can prevent a positive dialogue on nuclear matters, and may actually provide encouragement for those opposing accommodation with the nonproliferation regime.

\section{Maintain Support for Nonproliferation Norms and Further Nuclear Arms Reductions}

The U.S. has long supported the position widely held in the global community that the acquisition of nuclear weapons by additional states will create new dangers in the international system. This international nuclear nonproliferation norm has created a bistory in which, rather than achieving status, proliferant states are labeled as "rogues," suffer a loss of international standing, and are denied access to institutions, trade, and technology. The desire to avoid being placed in this category influenced nuclear rollback decisions in both Argentina and Brazil, but was a stronger factor for Argentina.

\section{E. Economic Considerations Play an Increasing Role}

U.S. global economic and technological leadership provides vital leverage in its nonproliferation policies. Thus, the United States should design nonproliferation policies that successfully motivate nuclear rollback policies in states seeking advanced technology, international investment, improved national economic performance, and strengthened national security. The desire to participate in civilian nuclear projects, other energy-related industrial partnerships, and public/private commercial technology development programs provided motivations to foreswear nuclear arms in both Argentina and Brazil.

\section{Conclusion}

The cases of nuclear rapprochement in Argentina and Brazil highlight the limits of U.S. nonproliferation policy and the importance of domestic and economic factors in deciding proliferation outcomes. They also demonstrate the fundamental importance of indigenous bilateral and regional nuclear nonproliferation mechanisms. Such mechanisms can be better attuned to the needs-perceived or real $\longrightarrow$ of regional actors and may also provide political cover for accommodations with a multilateral regime. However, even in the cases of these two countries, U.S. policies sometimes reinforced, and sometimes undercut, those more decisive factors. Moreover, the recommendations summarized above and the more specific examples of positive U.S. actions in these cases described in the body of the report provide guidelines for nonproliferation policy that are relevant to other states of proliferation concern. Despite their relative weakness, the range of proliferation motivations that were present in these states demonstrates that the United States and the international community need to develop a range of nonproliferation policy tools that address these motivations and create incentives to foreswear nuclear arms. These issues will be further explored 
in subsequent workshops on South Africa and Ukraine. When assessed together with the results of this review of the Argentine and Brazilian experience, a richer understanding of the impact of various nonproliferation policy tools should emerge. 